\title{
PEMODELAN REKOMENDASI TEMPAT PEMBUANGAN SAMPAH SEMENTARA MENGGUNAKAN FUZZY OVERLAY DI KABUPATEN SEMARANG
}

\author{
${ }^{1}$ Gandhi Alip Wijayanto, ${ }^{2}$ Charitas Fibriani \\ Progdi Sistem Informasi fakultas Teknologi Informasi, Universitas Kristen Satya Wacana, \\ Salatiga \\ Email:1682015072@student.uksw.edu ${ }^{1}$,charitas.fibriani@uksw.edu²
}

(Diterima: 25 Agustus 2019, direvisi: 1 Desember 2019, disetujui: 4 Desember 2019)

\begin{abstract}
This study gave the recommendations for the construction of a temporary dumpsite to Dinas Lingkungan Hidup in Semarang District, which will be used as Semarang annual temporary dumpsite development plan. Dinas Lingkungan Hidup is having problems to determine the location for temporary dumpsite development. All this time, the current temporary dumpsite development is based on the place that is requested by the local community. This condition has taken effect for the next few years and will slow down the limited number of garbage trucks in carrying out their duties. GIS technology can be used to analyze spatial data of suitable locations for temporary dumpsite development by using the fuzzy overlay method to execute fuzzy logic. This method can be a bridge the fuzzy logic data. The fuzzification process was used to determine the value of variable membership with pre-determined parameters, it was followed by fuzzy overlay AND operations that analyze the results of fuzzification which fulfilling all pre-determined criteria. The analysis produced a map of recommendation locations for Temporary Dumpsite development that met all the pre-determined criteria.
\end{abstract}

Keyword:GIS, Fuzzy Logic, Fuzzy Overlay, Temporary Dumpsite

\begin{abstract}
ABSTRAK
Penelitian ini memberikan rekomendasi pembangunan tempat pembuangan sampah sementara kepada Dinas Lingkungan Hidup Kabupaten Semarang yang akan digunakan sebagai rencana pembangunan Tempat Pembangunan Sampah Sementara Kabupaten Semarang. Dinas terkait mengalami kendala menentukan lokasi untuk pembangunan lokasi Tempat Pembangunan Sampah Sementara karena pembangunan sekarang berdasarkan permintaan dari masyarakat setempat. Hal ini dinilai pembangunan yang tidak optimal untuk beberapa tahun mendatang dan akan memperlambat truk sampah yang berjumlah terbatas dalam menjalankan tugasnya mengingat setiap tahun Dinas Lingkunga Hidup membangun beberapa Tempat Pembangunan Sampah Sementara. Sistem Informasi Geografi dapat digunakan untuk menganalisis data spasial lokasi yang cocok untuk pembangunan Tempat Pembangunan Sampah Sementara. Menggunakan metode fuzzy overlay yang mengeksekusi fuzzy logic, dengan metode ini dapat menjembatani data yang bersifat fuzzy dapat digunakan bahasa mesin untuk berhitung. Proses fuzzification digunakan untuk mengetahui nilai keanggotaan variabel dengan parameter yang telah ditentukan, dilanjutkan menggunakan fuzzy overlay operasi AND yang menganalisis hasil fuzzification memenuhi semua kriteria yang telah ditentukan. Analisis tersebut menghasilkan peta lokasi rekomendasi untuk pembangunan Tempat Pembangunan Sampah Sementara yang memenuhi semua kriteria yang telah ditentukan.
\end{abstract}

Kata Kuncis: SIG, Fuzzy Logic, Fuzzy Overlay, Tempat Pembangunan Sampah Sementara

\footnotetext{
${ }^{1}$ Gandhi Alip Wijayanto, ${ }^{2}$ Charitas Fibriani, PEMODELAN REKOMENDASI LOKASI TEMPAT PEMBUANGAN SAMPAH SEMENTARA (TPSS) MENGGUNAKAN METODE FUZZY OVERLAY, STUDI KASUS: KABUPATEN SEMARANG
} 


\section{PENDAHULUAN}

Tempat Pembuangan Akhir (TPA) sampah di perkotaan merupakan masalah yang garus diperhatikan dalam perencanaan kota karena pemilihan lokasi TPA ini akan mempengaruhi kota dari sisi ekonomi, ekologi, dan kesehatan lingkungan [1]. Pertumbuhan penduduk di sebuah kota akan memberi dampak meningkatnya jumlah sampah yang dihasilkan, itulah kenapa perlu penataan untuk menentukan TPA sampah di perkotaan. Dimana pemerintah telah mengeluarkan peraturan bahwa sampah yang dihasilkan haruslah dikelola oleh pemerintah setempat [2].

Provinsi Jawa Tengah memiliki 29 kabupaten dan 6 kota. Salah satu kabupaten di Jawa Tengah adalah Kabupaten Semarang, dimana wilayah ini terletak pada posisi koordinat 110 14' 54,74" - 110 39' 3" Bujur Timur dan 7 3' 57" - 7 30'0" Lintang Selatan. Kabupaten Semarang memiliki 19 kecamatan, yang terbagi menjadi 27 kelurahan. Sebelah utara Kabupaten Semarang adalah Kota Semarang dan Kabupaten Demak. Sebelah selatan Kabupaten Semarang adalah Kabupaten Boyolali dan Kabupaten Magelang. Sebelah timur Kabupaten Semarang adalah Kabupaten Grobogan dan Kabupaten Boyolali. Sedangkan sebelah barat Kabupaten Semarang adalah Kabupaten Magelang dan Kabupaten Kendal [3].

Penyusunan Laporan Indeks Kualitas Lingkungan Hidup (IKLH) adalah tugas dari Dinas Lingkungan Hidup (DLH) Kabupaten Semarang. Laporan Indeks Kualitas Lingkungan Hidup (IKLH) adalah penggambaran keadaan lingkungan hidup di kawasan Kabupaten Semarang hubungannya dengan efek yang ditimbulkan karena aktifitas manusia yang memperngaruhi perubahan media lingkungan, baik air, udara maupun lahan/ hutan/ vegetasi.Termasuk laporan mengenai upaya dari pihak Kabupaten Semarang dalam mengatasi permasalahan lingkungan tersebut [4]. Salah satu permasalahan lingkungan yang dihadapi oleh DLH Kabupaten Semarang adalah permasalahan sampah, terkait dengan penentuan lokasi yang cocok untuk tempat pembuangan sampah sementara [5]. DLH mengalami kendala menentukan lokasi untuk pembangunan TPSS sesuai dengan variabel yang telah ditentukan karena pembangunan TPSS sekarang berdasarkan permintaan dari masyarakat setempat. hal ini dinilai pembangunan yang tidak optimal untuk beberapa tahun mendatang dan akan memperlambat truk sampah yang berjumlah terbatas dalam menjalankan tugasnya mengingat setiap tahun DLH membangun beberapa TPSS [6].

Teknologi Sistem Informasi Geografis (SIG) dapat digunakan untuk mendapatkan rekomendasi lokasi yang cocok untuk pembangunan TPSS [7]. Menggunakan metode fuzzy overlay dapat menghasilkan lokasi rekomendasi pembangunan TPSS dengan parameter variabel yang telah ditentukan sebagai inputan. Fuzzy overlay menggunakan fuzzy logic untuk menyelesaikan analisis kesesuaian pemilihan lokasi dengan cara fuzzification atau fuzzy membership mengubah nilai input menjadi 0 sampai 1 yang mengekspresikan kesesuaian masukan kemudian dilakukan overlay dengan operator yang dibutuhkan.

Penelitian ini bertujuan untuk memberikan rekomendasi lokasi yang cocok untuk pembangunan TPSS di Kabupaten Semarang menggunakan fuzzy overlay yang dapat digunakan sebagai rencana pembangunan TPSS tahunan DLH Kabupaten Semarang sesuai dengan kriteria yang telah ditentukan.

\section{TINJAUAN PUSTAKA}

Penelitian terdahulu yang membahas terkait pemodelan epidemi penyakit demam berdarah. Penelitian ini menggunakan logika fuzzy sebagai metode untuk menentukan tingkat kerawanan suatu daerah terhadap demam berdarah. Dimana daerah yang digunakan sebagai studi kasus adalah Kota Yogyakarta. Penelitian ini menggunakan variabel tingkat kepadatan bangunan, kepadatan penduduk (aspek manusia), persentase tutupan vegetasi, dan curah hujan (aspek lingkungan), dan house index (aspek kepadatan vektor). Seluruh parameter yang dihasilkan di setiap variabel memiliki fuzzy membership yang kemudian dianalisis menggunakan operator fuzzy dan hasilnya akan diklasifikasikan menerut tingkat kerentanan demam berdarah. Tingkat kerentanan DBD yang dihasilkan dari hasil klasifikasi kemudian diuji akurasinya terhadap kerentanan aktual yang diturunkan dari informasi sebaran kasus DBD di Kota Yogyakarta tahun 2007[8].

Pemodelan spasial multi-kriteria adalah salah satu komponen penting dari spatial decision support system (SDSS). Pemodelan spasial multi-kriteria sering membutuhkan skala nilai umum untuk input yang beragam dan berbeda untuk membuat analisis yang terintegrasi. Fungsi weighted overlay paling ${ }^{1}$ Gandhi Alip Wijayanto, ${ }^{2}$ Charitas Fibriani, PEMODELAN REKOMENDASI LOKASI TEMPAT PEMBUANGAN SAMPAH SEMENTARA (TPSS) MENGGUNAKAN METODE FUZZY OVERLAY, STUDI KASUS: KABUPATEN SEMARANG 
umum digunakan untuk analisis kesesuaian lokasi yang mengidentifikasi lokasi yang paling cocok untuk fenomena tertentu. Namun, fungsi weighted overlay memberikan hasil yang tidak konsisten dan hasil yang keliru untuk inputan yang salah karena mengasumsikan bahwa sebagian besar faktor yang paling menguntungkan menghasilkan nilai raster yang lebih tinggi, dalam mengidentifikasi lokasi terbaik Penelitian tersebut menyampaikan efektivitas fungsi fuzzy overlay untuk pemodelan spasial multi-kriteria. Hal ini didasarkan pada prinsip teori fuzzy logic yang mendefinisikan keanggotaan menggunakan fungsi Gaussian pada masing-masing input raster daripada memberikan peringkat tersendiri seperti dalam fungsi weighted overlay. Dengan menggunakan studi kasus tentang persiapan peta sumber daya lahan untuk blok Mawsynram di distrik Bukit Khasi Timur di Meghalaya, India. Dihasilkan fungsi fuzzy overlay telah memberikan hasil yang lebih memuaskan dalam hal kesesuaian lokasi sambil membandingkan dengan hasil dari fungsi weighted overlay [9].

Penelitian terdahulu yang membahas mengenai mencari daerah di Bandung Barat yang layak untuk lokasi TPA sampah yang memenuhi kriteria SNI No.19-3241-1994, dimana kriteria tersebut berhubungan dengan lingkungan hidup. Proses pemilihan terdiri dari 3 tahap penyaringan, yaitu: tahap penyaringan regional, penyisihan dan penetapan. Parameter yang digunakan yaitu: Geologi, Hidrogeologi, Hidrologi dan Tataguna Lahan [10]. Penelitian lain yang fokus mencari lokasi TPA sampah yang memenuhi kriteria SNI No.19-3241-1994, sejenis dengan penelitian [10] namun menggunakan studi kasus di tempat yang berbeda, yaitu di Kota Tebing Tinggi [11].

Penelitian ini memiliki persamaan dengan penelitian sebelumnya adalah penggunaan metode fuzzy overlay yang menggunakan fuzzy logic untuk mencari lokasi yang sesuai dengan variabel yang telah ditentukan. Dalam penelitian [9] membuktikan penggunaan fuzzy overlay lebih memuaskan dalam hal kesesuaian lokasi.

Fuzzy Logic adalah sebuah metode yang berhitung menggunakan variabel kata- kata dan bukan menggunakan variabel bilangan. Dimana kata- kata yang digunakan ini lebih mendekati dengan intuisi manusia karena mendekati dengan bahasa manusia sehari- hari, meskipun tidak sepresisi dengan variabel bilangan. Sehingga penggunakan fuzzy logic dalam penelitian memiliki nilai lebih karena kemampuannya yang dapat menjembatani bahasa mesin dengan bahasa manusia sehari- hari [12].

Fuzzy set berisi objek yang memenuhi syarat keanggotaan yang tidak tepat, yaitu, keanggotaan suatu objek dalam fuzzy set dapat diperkirakan. Sebagai contoh, ketinggian dari 5 hingga 7 kaki tepat (crisp); ketinggian di wilayah sekitar 6 kaki tidak tepat, atau kurang jelas. Untuk menguraikan, anggaplah kita memiliki koleksi lengkap elemen individu (singletons) $x$, yang membentuk semesta informasi (discourse), X. Selanjutnya, berbagai kombinasi elemen-elemen individual ini membentuk perangkat, katakanlah A, di alam semesta. Untuk crisp set, elemen $x$ di alam semesta $\mathrm{X}$ adalah anggota dari beberapa crisp set A atau tidak. Masalah keanggotaan biner ini dapat direpresentasikan secara matematis dengan fungsi indikator seperti dapat dilihat pada persamaan 1 .

$$
\chi A(x)=\left\{\begin{array}{l}
1, x \in A, j i k a \text { A memenuhi syarat keanggotaan } \\
0, x \notin A, j i k a \text { A tidak memenuhi syarat keanggotaan }
\end{array}\right.
$$

simbol $\chi A(x)$ memberikan indikasi keanggotaan elemen $x$ yang tidak ambigu dalam himpunan $\mathrm{A}$, dan simbol $\in$ dan $\notin$ menunjukkan masing-masing yang termasuk dan tidak termasuk [13].

Fungsi transformasi Fuzzy Linear menerapkan fungsi linear antara nilai minimum dan maksimum yang ditentukan. Apa pun yang bernilai dibawah minimum akan bernilai 0 (pasti bukan anggota) dan apa pun yang bernilai diatas maksimum bernilai 1 (pasti anggota). Jika nilai minimum lebih besar dari maksimum, maka membentuk hubungan linear negatif (kemiringan negatif) dan sebaliknya [13]. Fuzzy Overlay adalah tools software SIG yang memungkinkan analisis variabel yang dimiliki oleh beberapa set dalam multicriteria overlay analysis. Fuzzy overlay tidak hanya menentukan variabel apa saja yang mungkin menjadi anggota, tetapi juga menganalisis hubungan antara keanggotaan beberapa set. Tipe Overlay mencantumkan metode yang tersedia untuk menggabungkan data berdasarkan analisis teori himpunan. Setiap metode memungkinkan eksplorasi keanggotaan masing-masing sel yang dimiliki berbagai input. Metode yang tersedia adalah fuzzy AND, OR, PRODUCT, SUM dan GAMMA [14]. Setiap pendekatan memberikan aspek berbeda dari keanggotaan masing-masing sel dengan beberapa kriteria input .

${ }^{1}$ Gandhi Alip Wijayanto, ${ }^{2}$ Charitas Fibriani,

PEMODELAN REKOMENDASI LOKASI TEMPAT PEMBUANGAN SAMPAH SEMENTARA (TPSS) MENGGUNAKAN METODE FUZZY OVERLAY, STUDI KASUS: KABUPATEN SEMARANG 
Fuzzy overlay AND mengembalikan nilai minimum set lokasi milik sel. Teknik ini berguna ketika ingin mengidentifikasi variabel paling umum untuk keanggotaan dari semua kriteria yang diinputkan [11].

$$
\text { fuzzyAndValue }=\min (\arg 1, \ldots, \operatorname{argn})
$$

\section{METODE PENELITIAN}

Penelitian ini dibagi 4 tahap penelitian, yaitu: Perumusan Masalah, Pengumpulan dan Persiapan Data, Pengolahan dan Analisis Data, dan Analisis Hasil (Error! Reference source not found.).

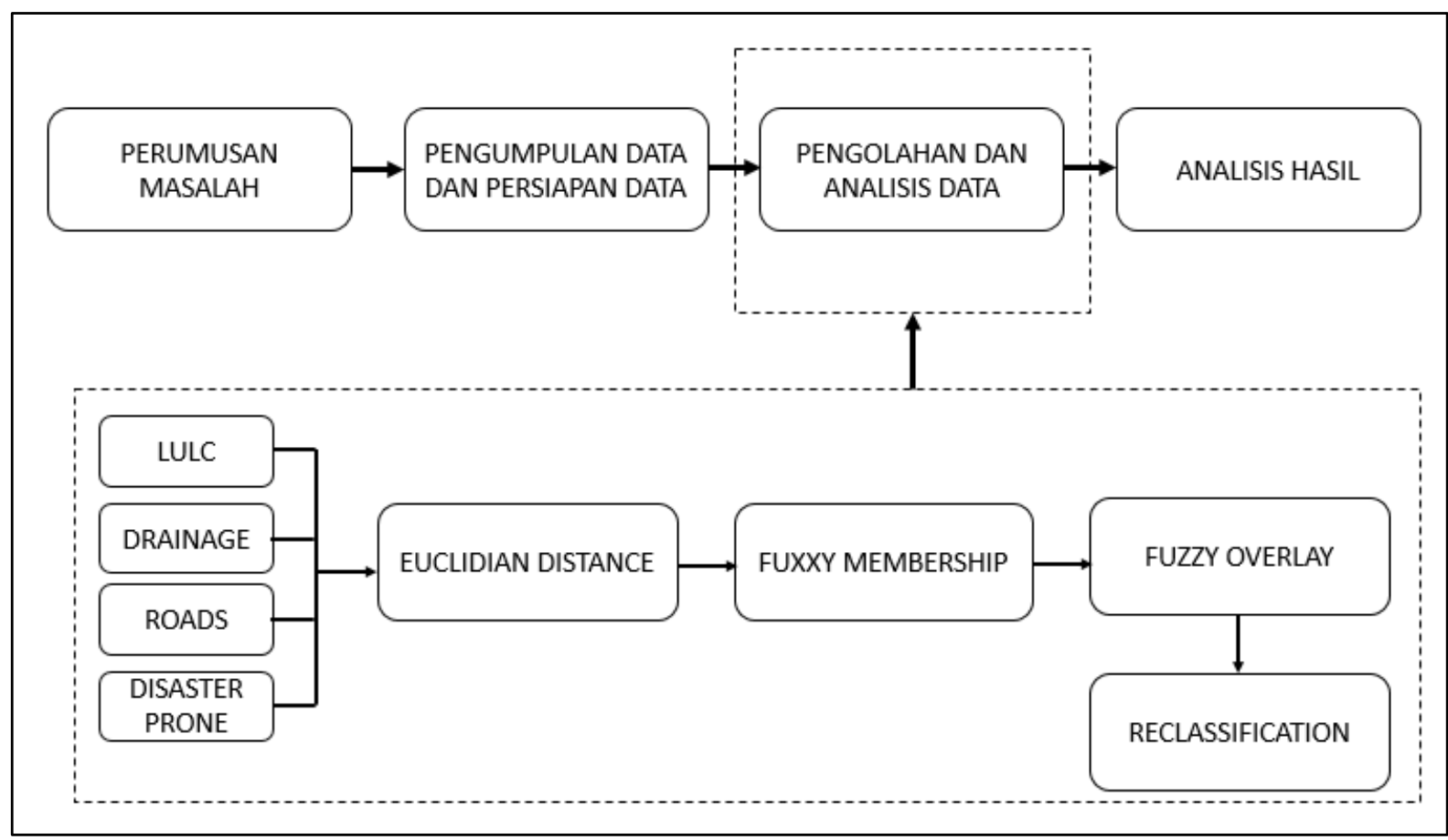

Gambar 1 Alur tahap penelitian

Tahap pertama, perumusan masalah dilakukan wawancara kepada Kepala Bidang I Peningkatan Kapasitas Lingkungan Hidup DLH Kabupaten Semarang dan didapat masalah kesulitan menentukan lokasi untuk pembangunan TPSS di Kabupaten Semarang. Tahap kedua, pengumpulan dan persiapan data didapat data primer dan sekunder. Data primer yang didapat adalah hasil wawancara kepada Kepala Bidang I Peningkatan Kapasitas Lingkungan Hidup DLH Kabupaten Semarang yang berupa rumusan masalah dan parameter untuk analisis data. Data sekunder yang didapat adalah data spasial berupa data shapefile (.SHP) Kabupaten Semarang tahun 2018 berbentuk dot (titik), polygon dan polyline [15] yang didapat dari Badan Perencanaan, Penelitian, dan Pengembangan Daerah (BARENLITBANGDA) Kabupaten Semarang. Kemudian data dikumpulkan untuk digunakan pada tahap selanjutnya. Data yang terkumpul yaitu: jaringan drainase, jaringan jalan, sungai, wilayah perairan, wilayah pemukiman, bangunan, daerah rawan bencana, dan wilayah hutan Kabupaten Semarang. Tahap ketiga, Pengolahan dan analisis data menggunakan software SIG. Data yang sudah terkumpul diolah, data dikelompokkan sesuai dengan parameter yang sama dan digabungkan menjadi satu dengan tool software SIG, dilanjutkan dengan tool Euclidean distance untuk mendapatkan data raster. Didapatkan empat data utama, yaitu: Drainage sebagai parameter pencemaran air dari penggabungan data jaringan drainase dan sungai, Land Use and Land Cover (LULC) sebagai parameter tata runag dan estetika dari penggabungan data wilayah perairan, wilayah hutan hutan, wilayah pemukiman, dan bangunan, Roads sebagai parameter aksesibilitas dari data jaringan jalan, dan Disaster Prone sebagai parameter daerah rawan bencana dari data daerah rawan bencana. Pengolahan data diteruskan dengan proses fuzzification

${ }^{1}$ Gandhi Alip Wijayanto, ${ }^{2}$ Charitas Fibriani,

PEMODELAN REKOMENDASI LOKASI TEMPAT PEMBUANGAN SAMPAH SEMENTARA (TPSS) MENGGUNAKAN METODE FUZZY OVERLAY, STUDI KASUS: KABUPATEN SEMARANG 
dengan tool fuzzy membership untuk mengetahui keanggotaan dari parameter yang telah ditentukan, tahap terakhir analisis menggunakan fuzzy overlay menggunakan operator AND dan reclassification untuk menghasilkan analisis lokasi rekomendasi lokasi pembangunan TPSS. Tahap penulisan hasil analisis dilakukan dengan penulisan hasil pengolahan dan analisa data berupa peta rekomendasi lokasi yang cocok untuk pembangunan TPSS di Kabupaten Semarang.

\section{HASIL DAN PEMBAHASAN}

Penelitian ini hendak menemukan rekomendasi lokasi yang cocok untuk pembangunan TPSS di Kabupaten Semarang. Data spasial yang digunakan berjenis shapefile, yaitu: jaringan drainase, jaringan jalan, sungai, wilayah perairan, wilayah pemukiman, bangunan, daerah rawan bencana, dan wilayah hutan Kabupaten Semarang. Data dikelompokkan sesuai dengan parameter yang sama dan digabungkan menjadi satu dengan tool software SIG, dilanjutkan dengan tool Euclidean distance untuk mendapatkan data jarak.

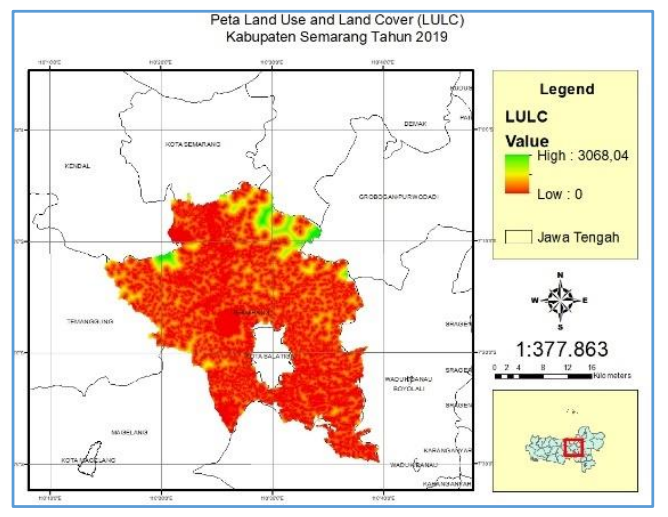

Gambar 2 Peta LULC

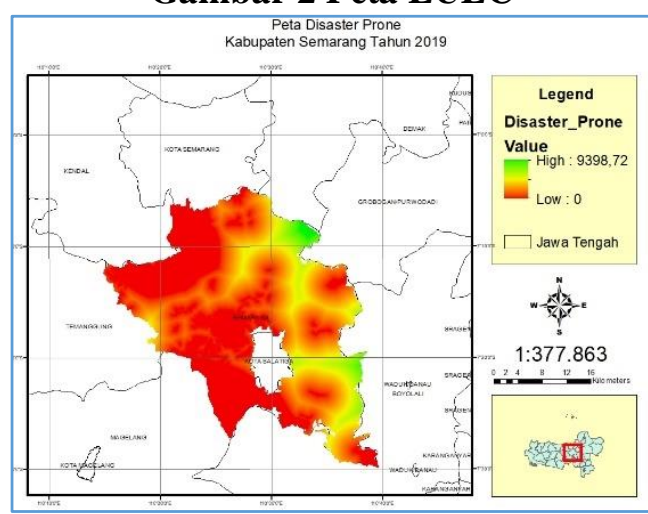

Gambar 4 Peta Disaster prone
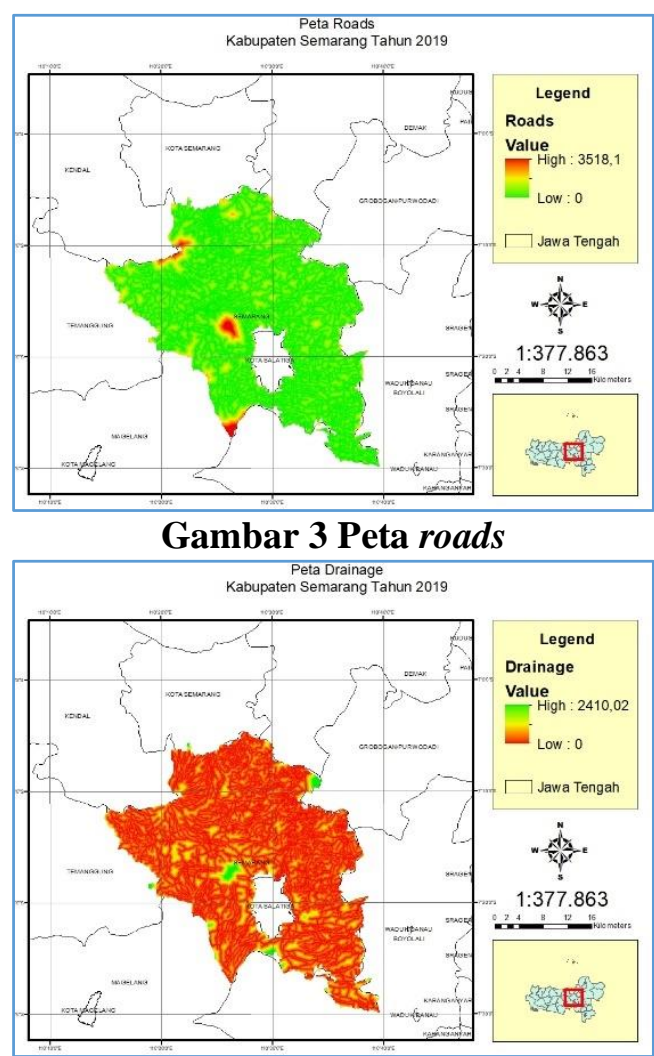

Gambar 5 Peta drainage

Data dan parameter yang didapat dapat dilihat pada Tabel 1:

Tabel 1 Tabel Data dan Parameter

\begin{tabular}{cll}
\hline No. & \multicolumn{1}{c}{ Data } & \multicolumn{1}{c}{ Sebagai Parameter } \\
\hline 1 & LULC (Gambar 2) & Tata Ruang dan Estetika \\
2 & Roads (Gambar 3) & Aksesibilitas \\
3 & Disaster Prone (Gambar 4) & Daerah Rawan Bencana \\
4 & Drainage (Gambar 5) & Pencemaran Air \\
\hline
\end{tabular}

LULC sebagai parameter tata ruang dan estetika dari penggabungan data wilayah perairan, wilayah hutan hutan, wilayah pemukiman, dan bangunan dapat dilihat pada Gambar 2, Roads sebagai parameter aksesibilitas dari data jaringan jalan dapat dilihat pada Gambar 3, Disaster Prone sebagai

${ }^{1}$ Gandhi Alip Wijayanto, ${ }^{2}$ Charitas Fibriani,

PEMODELAN REKOMENDASI LOKASI TEMPAT PEMBUANGAN SAMPAH SEMENTARA (TPSS) MENGGUNAKAN METODE FUZZY OVERLAY, STUDI KASUS: KABUPATEN SEMARANG 
parameter daerah rawan bencana dari data daerah rawan bencana dapat dilihat pada Gambar 4, dan Drainage sebagai parameter pencemaran air dari penggabungan data jaringan drainase dan sungai dapat dilihat pada Gambar 5

\subsection{Fuzzification}

Data hasil Euclidean distance diproses lebih lanjut dengan fuzzification (fuzzy membership) sesuai dengan parameter masing - masih yang telah ditentukan dari wawancara Kepala Bidang I Peningkatan Kapasitas Lingkungan Hidup DLH Kabupaten Semarang.

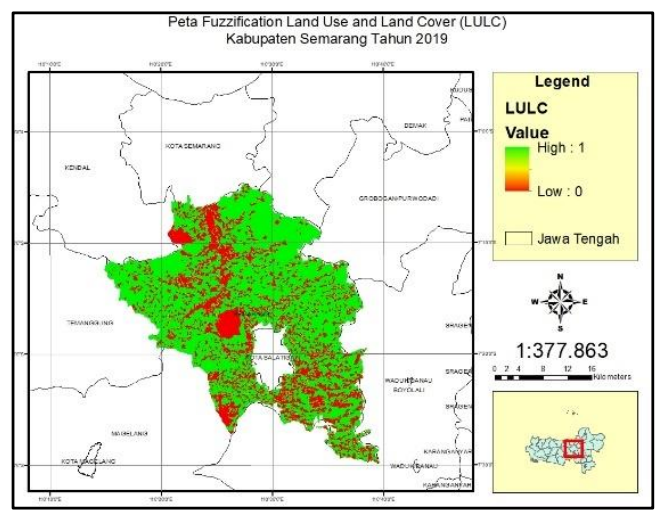

Gambar 6 Peta fuzzification LULC

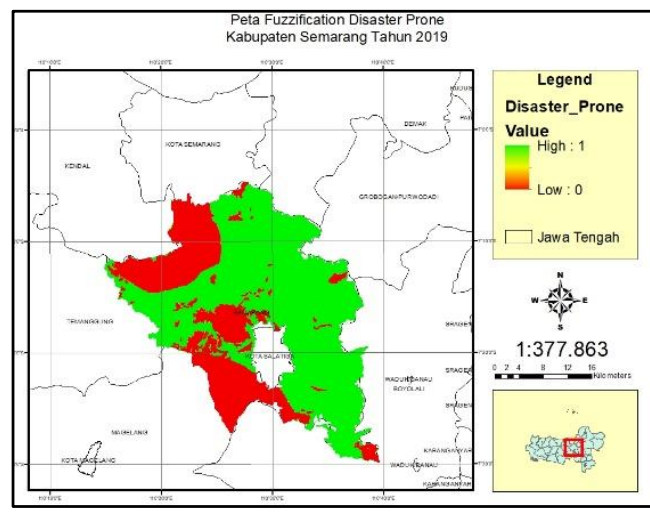

Gambar 8 Peta fuzzification disaster prone
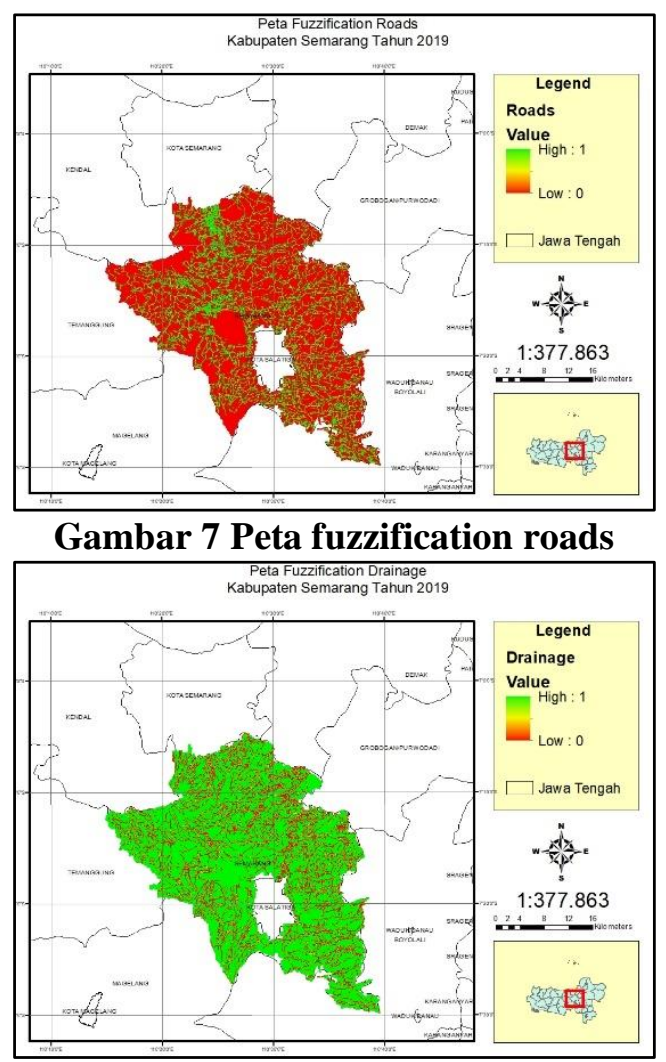

Gambar 9 Peta fuzzification drainage

Proses fuzzification data menggunakan fungsi linear dengan hasil seperti pada Tabel 2 :

Tabel 2 Tabel Fuzzification

\begin{tabular}{c|l|c|c}
\hline \multirow{2}{*}{ No. } & \multicolumn{1}{|c}{ Data } & \multicolumn{2}{c}{ Nilai $X$ (Jarak) } \\
\cline { 3 - 4 } & & X Minimum & X Maximum \\
\hline 1 & LULC (Gambar 6) & $30 \mathrm{~m}$ & $50 \mathrm{~m}$ \\
2 & Roads (Gambar 7) & $50 \mathrm{~m}$ & $10 \mathrm{~m}$ \\
3 & Disaster Prone (Gambar 8) & $0 \mathrm{~m}$ & $100 \mathrm{~m}$ \\
4 & Drainage (Gambar 9) & $30 \mathrm{~m}$ & $50 \mathrm{~m}$ \\
\hline
\end{tabular}

LULC dengan $X \min =30$ dan $X \max =50$ pada Gambar 6 membentuk fungsi linear positif, jika $X$ kurang dari 30 meter maka bukan anggota (bernilai 0 ) dan jika $X$ lebih dari 50 meter merupakan anggota pasti (bernilai 1). Fuzzification roads dengan parameter Xmin $=50$ dan Xmax $=10$ pada Gambar 7 membentuk fungsi linear negatif, jika $X$ kurang dari 10 meter maka merupakan anggota anggota pasti (bernilai 1) dan jika $X$ lebih dari 50 meter maka bukan anggota (bernilai 0). Fuzzification disaster prone

${ }^{1}$ Gandhi Alip Wijayanto, ${ }^{2}$ Charitas Fibriani, PEMODELAN REKOMENDASI LOKASI TEMPAT PEMBUANGAN SAMPAH SEMENTARA (TPSS) MENGGUNAKAN METODE FUZZY OVERLAY, STUDI KASUS: KABUPATEN SEMARANG 
dengan parameter $X \min =0$ dan $X \max =100$ pada Gambar 8 membentuk fungsi linear positif, jika $X$ lebih dari 100 meter merupakan anggota pasti (bernilai 1). Sedangkan fuzzification drainage dengan parameter $X \min =30$ dan Xmax $=50$ pada Gambar 9 membentuk fungsi linear positif, jika $X$ kurang dari 30 meter maka bukan anggota (bernilai 0) dan jika $X$ lebih dari 50 meter merupakan anggota pasti (bernilai 1).

\subsection{Fuzzy Overlay}

Data fuzzification akan dianalisis mengguanakan tool fuzzy overlay dengan operator AND. Dengan menggunakan operator AND akan mengembalikan nilai dimana semua variable memiliki nilai atau $X \neq 0$, hal ini dilakukan untuk mendapatkan rekomendasi lokasi untuk pembangunan TPSS yang baru di Kabupaten Semarang tahun 2019 lebih akurat (Gambar10).

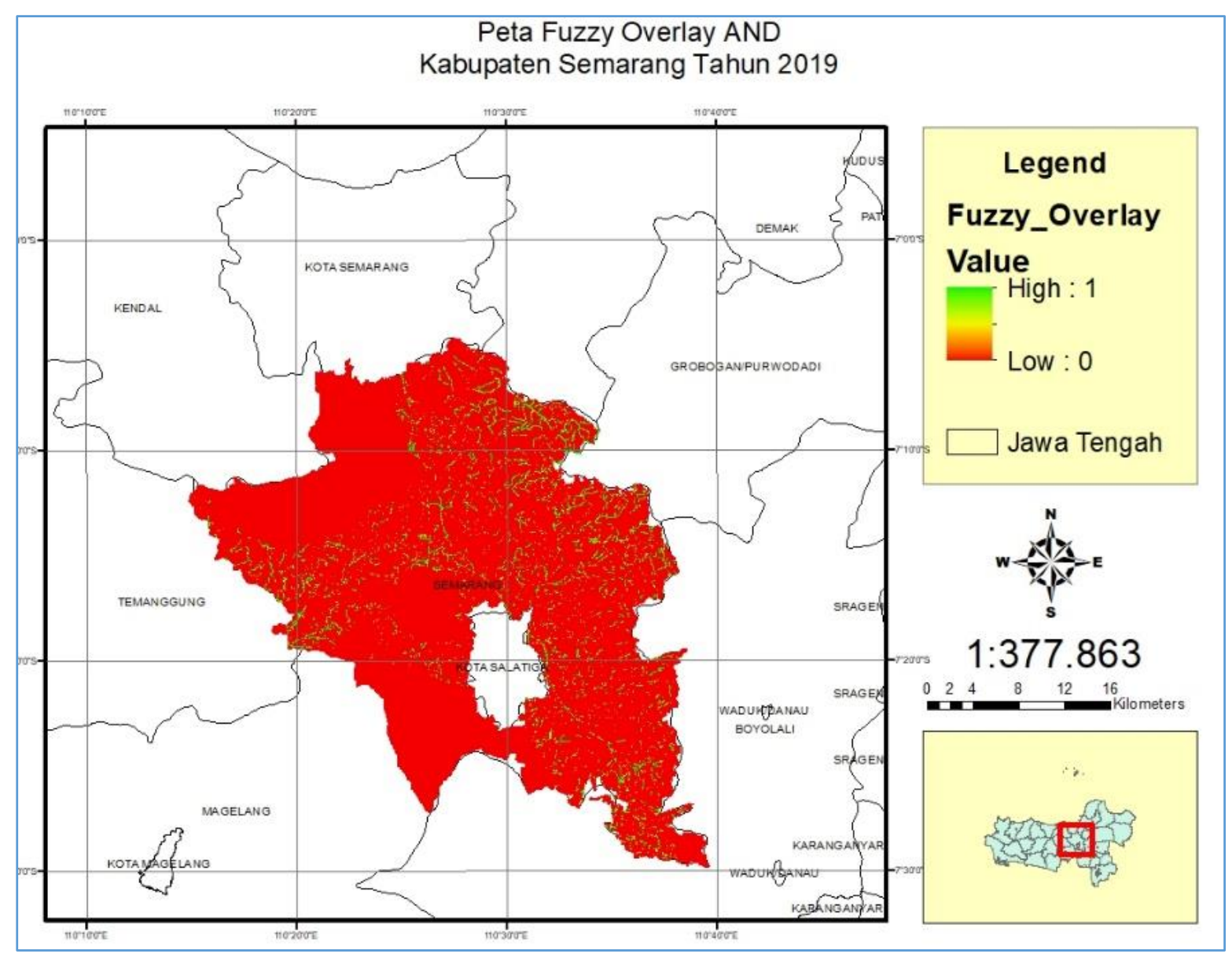

Gambar 10 Peta fuzzy overlay operator AND

Hasil yang sudah didapat selanjutnya di-reclassify menjadi 4 kelas dengan daerah yang paling cocok akan mendapatkan nilai tertinggi (4) dengan label "Sangat Cocok" dan yang tidak cocok akan diberi nilai terendah (1) dengan label "Tidak Cocok" untuk rekomendasi pembangunan TPSS baru pada tahun 2019 (Gambar 11).

${ }^{1}$ Gandhi Alip Wijayanto, ${ }^{2}$ Charitas Fibriani, 


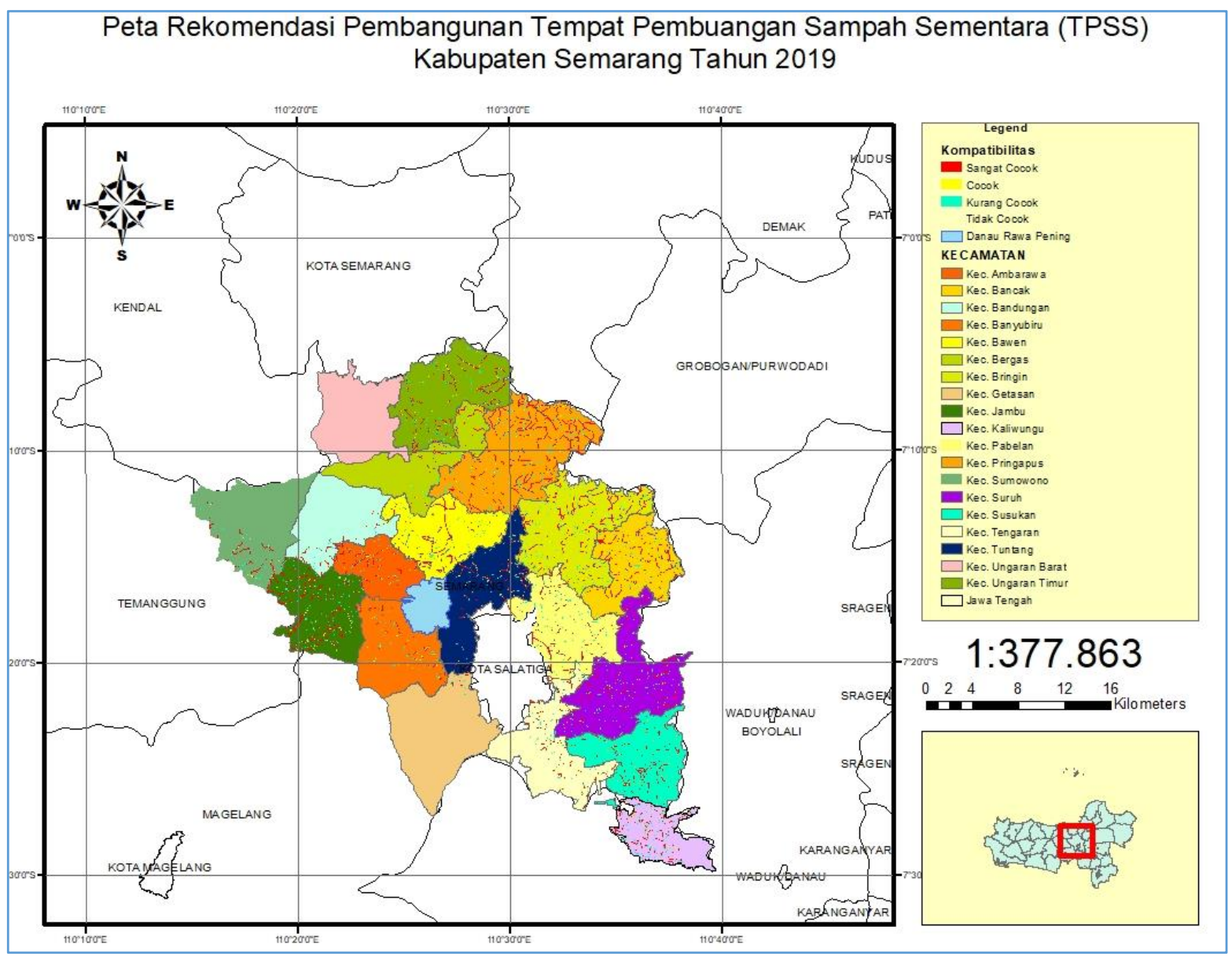

Gambar 11 Peta rekomendasi pembangunan TPSS

Dapat dilihat hasil proses fuzzy overlay operator AND mengembalikan nilai dimana semua kriteria memiliki nilai atau $X \neq 0$. Jika salah satu kriteria memiliki nilai $X=0$ (bukan anggota) akan diklasifikasi dengan label 1 (Tidak Cocok) dan jika semua kriteria memiliki nilai $X=1$ (pasti anggota) akan diklasifikasikan dengan label 4 (Sangat Cocok). Pada Gambar 11 terlihat semua kecamatan di Kabupaten Semarang memiliki lokasi yang cocok untuk dijadikan lokasi pembangunan TPSS. Pada Kecamatan Ungaran Barat, Kecamatan Bergas, Kecamatan Bandungan dan Kecamatan Sumowono yang berlokasi dikaki Gunung Ungaran tidak cocok untuk lokasi pembangunan TPSS karena merupakan daerah rawan bencana gunung meletus, seperti halnya pada wilayah bagian selatan Kecamatan Banyubiru, Kecamatan Getasan dan Kecamatan Tengaran yang tidak cocok untuk lokasi pembangunan TPSS karena merupakan daerah rawan bencana banjir dan tanah longsor.

\section{KESIMPULAN}

Pencarian rekomendasi lokasi yang cocok untuk pembangunan TPSS di Kabupaten Semarang sebagai rencana pembangunan TPSS tahunan DLH Kabupaten Semarang sesuai dengan kriteria yang telah ditentukan menggunakan fuzzy overlay. Data spasial yang digunakan berupa data shapefile (.SHP) Kabupaten Semarang tahun 2018 berbentuk dot (titik), polygon dan polyline yang didapat dari Badan Perencanaan, Penelitian, dan Pengembangan Daerah (BARENLITBANGDA) Kabupaten Semarang dan menggunakan parameter dari hasil wawancara kepada Kepala Bidang I Peningkatan Kapasitas Lingkungan Hidup DLH Kabupaten Semarang. Fuzzy overlay mengeksekusi fuzzy logic menggunakan parameter data yang dimasukkan dimana data yang bersifat fuzzy dapat digunakan dalam bahasa mesin untuk melakukan analisis. Hasil analisis mendapatkan lokasi - lokasi yang cocok untuk pembangunan TPSS di Kabupaten Semarang, pada Gambar 11 terlihat semua kecamatan di Kabupaten Semarang memiliki lokasi yang cocok untuk dijadikan lokasi pembangunan TPSS. Pada Kecamatan Ungaran

${ }^{1}$ Gandhi Alip Wijayanto, ${ }^{2}$ Charitas Fibriani,

PEMODELAN REKOMENDASI LOKASI TEMPAT PEMBUANGAN SAMPAH SEMENTARA (TPSS) MENGGUNAKAN METODE FUZZY OVERLAY, STUDI KASUS: KABUPATEN SEMARANG 
Barat, Kecamatan Bergas, Kecamatan Bandungan dan Kecamatan Sumowono yang berlokasi dikaki Gunung Ungaran tidak cocok untuk lokasi pembangunan TPSS karena merupakan daerah rawan bencana gunung meletus, seperti halnya pada wilayah bagian selatan Kecamatan Banyubiru, Kecamatan Getasan dan Kecamatan Tengaran yang tidak cocok untuk lokasi pembangunan TPSS karena merupakan daerah rawan bencana banjir dan tanah longsor. Diharapan untuk penelitian selanjutnya menggunakan parameter yang lebih lengkap seperti penambahan data jumlah penduduk perdesa untuk mendapatkan jumlah dan volume TPSS yang akan dibangun

\section{REFERENSI}

[1] V. Akbari and S. H. Chavoshi, "Landfill site selection by combining GIS and fuzzy multi criteria decision analysis, case study: Bandar Abbas, Iran Landfill Site Selection by Combining GIS and Fuzzy Multi Criteria Decision Analysis , Case Study : Bandar Abbas , Iran,” no. May 2014, 2008.

[2] Anonim, "UNDANG-UNDANG REPUBLIK INDONESIA NOMOR 18 TAHUN 2008 TENTANG PENGELOLAAN SAMPAH," Jakarta, 2008.

[3] P. K. Semarang, "Geografi dan Topografi Kabupaten Semarang," 27 Juni, 2011. [Online]. Available: http://www.semarangkab.go.id/utama/selayang-pandang/kondisi-umum/geografitopografi.html.

[4] D. L. H. K. Semarang, "Dinas Lingkungan Hidup Kab. Semarang," 2018. [Online]. Available: http://dlh.semarangkab.go.id/.

[5] D. L. H. K. Semarang, "SAMPAH PEMPERS BUTUH PERHATIAN SERIUS," 2018. [Online]. Available: http://dlh.semarangkab.go.id/?p=2442.

[6] Anonim, "SNI 19-3241-1994 tentang Tata Cara Pemilihan Lokasi Tempat Pembuangan Akhir Sampah," Jakarta, 1994.

[7] E. Budiayanto, Sistim Informasi Geografis dengan ArcView GIS. yogyakarta: Penertbit Andi, 2009.

[8] G. Adzan and P. Danoedoro, "PENGGUNAAN LOGIKA FUZZY DALAM PEMODELAN SPASIAL KERENTANAN DBD DI KOTA YOGYAKARTA,” J. Bumi, vol. 1, pp. 59-70, Jan. 2012.

[9] P. Baidya et al., "Effectiveness of Fuzzy Overlay Function for Multi-Criteria Spatial Modeling - A Case Study on Preparation of Land Resources Map for Mawsynram Block of East Khasi Hills District of Meghalaya, India," J. Geogr. Inf. Syst., vol. 06, pp. 605-612, Jan. 2014.

[10] O. D. Anggraini and B. Rahardyan, "Pemilihan Calon Lokasi TPA Dengan Metode Gis Di Kabupaten Bandung Barat," J. Progr. Stud. Tek. Lingkung., 2009.

[11] Hasibuan Putra Amantha, Tarigan Ahmad Perwira Mulia and Nasution Zaid Perdana, "STUDI PEMILIHAN LOKASI TEMPAT PEMBUANGAN AKHIR (TPA) SAMPAH DENGAN METODE SISTEM INFORMASI GEOGRAFIS (SIG) DI KOTA TEBING TINGGI," J. Tek. Sipil USU, no. 19, pp. 1-9, 2008.

[12] A. Naba, tutorial cepat \& mudah fuzzy logic dengan matlab. yogyakarta: andi, 2009.

[13] T. J. Ross, FUZZY LOGIC WITH ENGINEERING ENGINEERING Third Edition, 3rd ed. Chickchester: John Wiley \& Sons Ltd, 2010.

[14] ArcGIS, "How Fuzzy Overlay works," 2016. [Online]. Available: https://desktop.arcgis.com/en/arcmap/10.3/tools/spatial-analyst-toolbox/how-fuzzy-overlayworks.htm.

[15] D. Gumelar, Data Spasial. Bandung: IlmuKomputer.com, 2007.

\footnotetext{
${ }^{1}$ Gandhi Alip Wijayanto, ${ }^{2}$ Charitas Fibriani, PEMODELAN REKOMENDASI LOKASI TEMPAT PEMBUANGAN SAMPAH SEMENTARA (TPSS) MENGGUNAKAN METODE FUZZY OVERLAY, STUDI KASUS: KABUPATEN SEMARANG
} 